\title{
Продуктивность и биометрические показатели плодов томата в зависимости от освещенности
}

\section{Е.В. Соколова, В.М. Мерзлякова}

К выращиванию в защищенном грунте в условиях Удмуртской Республики можно рекомендовать индетерминантный гибрид томата $F_{1}$ Тореро на кокосовом субстрате. Результаты исследований 2017-2018 годов показали, что освещение влияло на количество плодов на растении (соответственно, $r$ = $0,56$ и 0,71$)$ и на количество плодоносящих кистей на растении (соответственно, $r=0,90$ и 0,82).

Ключевые слова: томат, урожайность, зимне-весенний оборот, освещенность, защищенный грунт, биометрические показатели томата.

$\Pi$ о данным национального плодоовощного союза России [1] в 2017 году выращено 984 тыс. т овощей защищенного грунта, в том числе производство томатов увеличилось на 25\% до 331 тыс. т. Урожайность овощей и качество плодов, выращенных в условиях Удмуртской Республики в открытом и защищенном грунте существенно отличается друг от друга [2-10]. В качестве грунта используют искусственные среды или субстраты (как органические, так и минеральные). Сегодня в тепличных хозяйствах широко используют минеральную вату, кокосовое волокно [11, 12]. Жителей Удмуртской Республики более сорока лет свежими овощами и зеленью обеспечивает АO «Тепличный комбинат «Завьяловский». Выращивание томата в теплицах дает возможность получать урожай и обеспечивать потребителей продукцией практически круглый год. Ограничивающим фактором является низкая освещенность в осенний и зимний периоды. Световая энергия - это один из важнейших факторов жизнедеятельности растений томата, в большей степени определяющий их продуктивность и качество продукции. Свет используется в качестве источника энергии для преобразования хлорофиллом неорганических веществ в органические вещества. Многочисленными исследованиями доказано, что растениям томата для нормального роста и развития необходимо освещение в течение 12-16 часов в сутки, а при сокращении освещенности до 10 часов они перестают давать полноценный урожай. Поэтому в условиях Удмуртской Республики в теплицах применяют искусственное освещение.

Цель исследований: оценить влияние освещенности на продуктивность и биометрические показатели растений томата.

Исследования провели в зимне-весеннем обороте на томатах $\mathrm{F}_{1}$ Тореро и $\mathrm{F}_{1}$ Адмиро при выращивании на различных субстратах в условиях $\mathrm{AO}$ «Тепличный комбинат «Завьяловский».

Влияние уровня освещенности на урожайность и биометрические показатели томата определяли в двухфакторном опыте. Фактор А - индетерминантные гибриды томата $F_{1}$ Тореро (к), $F_{1}$ Адмиро; фактор B - субстраты: минеральная вата
«Субстрат «Урожайный» (м.в. 1) (к), минеральная вата «Волга-Рост» (м.в. 2), кокосовое волокно. Размещение вариантов - методом полной рендомизации, площадь учетной делянки составила 3,3 м². Общая площадь опыта - 89,1 м². Размещение растений в теплице - рядовое. Технология возделывания зимне-весенней культуры томата методом малообъемной технологии общепринятая. Биометрические показатели определяли по общепринятым методикам. Учет урожая проводили в динамике, взвешиванием плодов с каждой делянки при каждом сборе, с последующим пересчетом в килограммы с $1 \mathrm{M}^{2}$. Показатели уровня освещенности определяли с помощью компьютерных программ.

Полученные в результате проведения исследований данные подвержены статистической обработкой дисперсионным методом по Б.А. Доспехову [13] с использованием компьютерной программы Microsoft Excel.

Изучаемые гибриды томата характеризовались высокой ранней

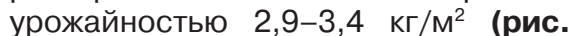
1). Наибольшая общая урожайность в 2017 году получена в варианте

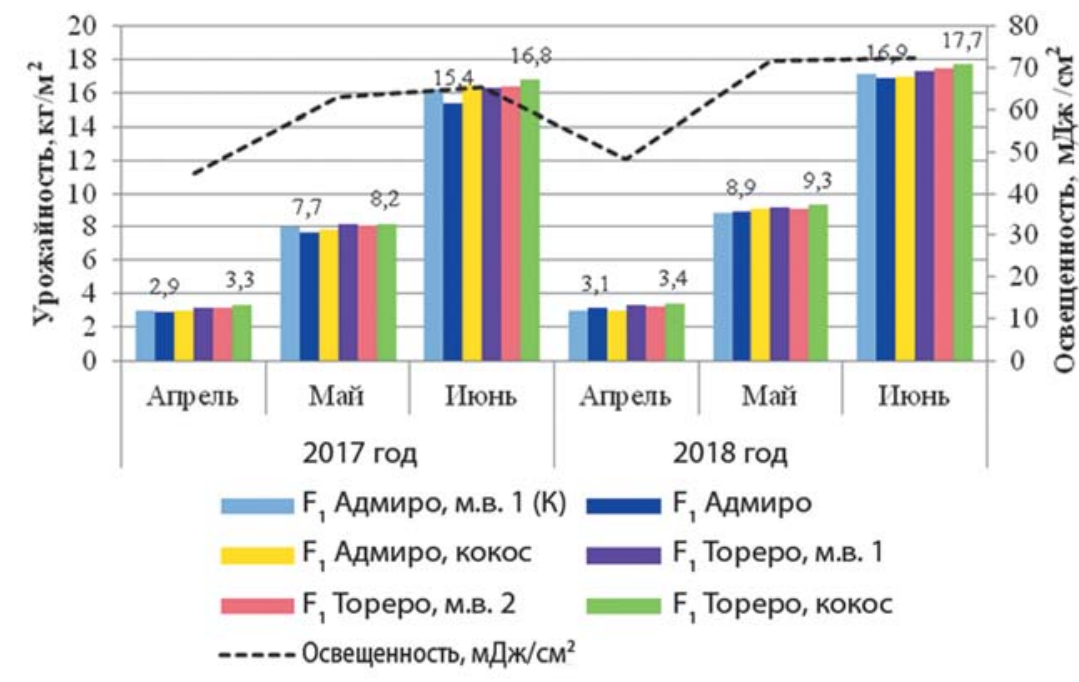

Рис. 1. Урожайность томата в зависимости от освещения, кг/M² 


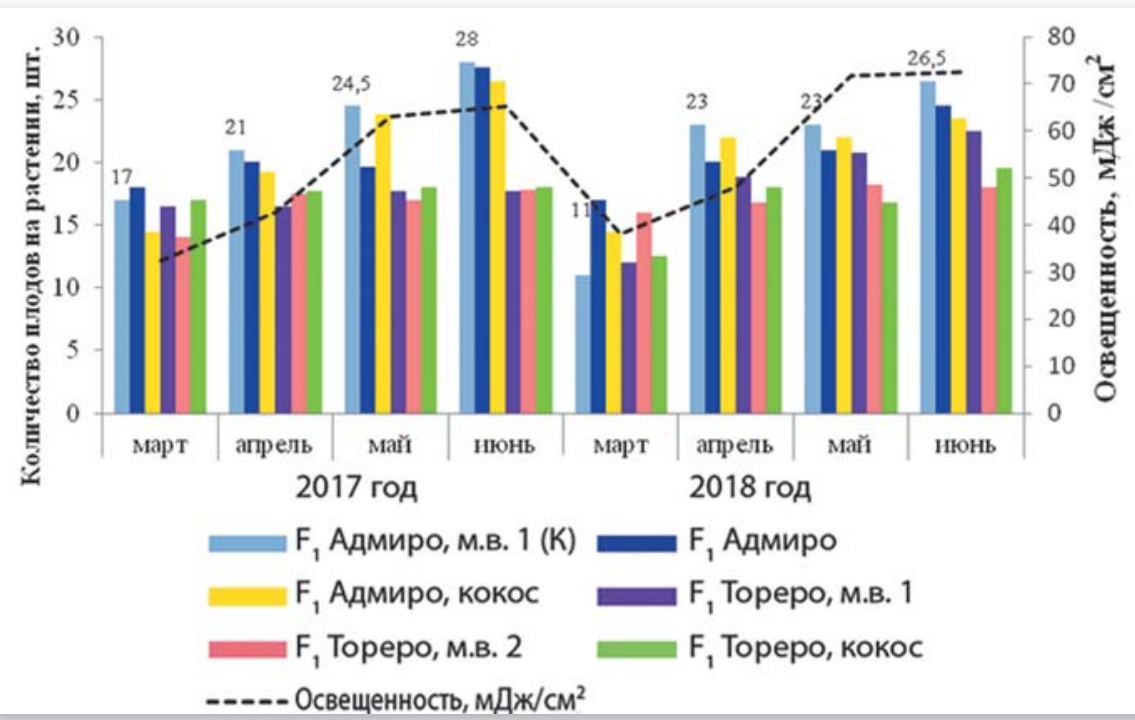

Pис. 2. Количество плодов на растении томата в зависимости от освещенности, шт.

с выращиванием гибрида $F_{1}$ Тореро на кокосовом субстрате - 16,8 кг/ $\mathrm{M}^{2}$, что выше контрольного варианта на 0,6 кг/м² при НСР 05 частных

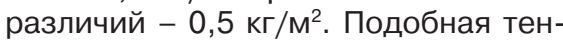
денция наблюдалась и в 2018 году. Освещенность увеличилась за данный период с 48104 до 72497 Дж/см². Массовый сбор плодов томатов в условиях Удмуртской Республики приходится на июнь месяц. Но существенных отличий между вариантами не было. Как в 2017, так и в 2018 году отмечена сильная положительная корреляция между уровнем освещенности и урожайностью томата ( $r=0,80$ и 0,81 соответственно).

В течение двух лет изучали изменение длины растений, количество плодоносящих кистей на растении и количество плодов в динамике. В наших исследованиях прирост растений изменяли в пределах 18,0-26,3 см. Этот показатель существенно отличался у изучаемых гибридов томата и зависел от уровня освещенности. В 2017 и 2018 годах нами получена обратная сильная корреляция между урожайностью гибридов томата и освещенностью $(r=-0,81$ и -0,77 соответственно).

В 2017 году количество плодов на растении томата варьировало от 14,0 шт. в марте до 28,0 шт. в июне. Наибольшее их количество получено в варианте с гибридом томата $F_{1}$ Тореро при выращивании на кокосовом субстрате. С увеличением освещенности с марта по июнь количество плодов на растении увеличивалось $(r=0,56)$. Условия 2018 года были более благоприятны по уровню освещенности, и также с ее увеличением количество плодов на рас- тении увеличивалось. Получена прямая сильная корреляция от этого показателя, $r=0,71$ (рис. 2).

Наиболее зависимым от освещенности показателем оказалось количество плодоносящих кистей на растении. С увеличением освещенности данный показатель также увеличивался, отмечена положительная сильная корреляция $r=0,90$ в 2017 году и $r=0,82$ в 2018 году. Гибрид томата $F_{1}$ Тореро более активно реагировал на изменение освещенности в течение четырех месяцев, и количество кистей на растении у этого гибрида было больше, чем у гибрида $F_{1}$ Адмиро. Субстраты на этот показатель не влияли.

Таким образом, к выращиванию в защищенном грунте в условиях Удмуртской Республики можно рекомендовать индетерминантный гибрид томата $F_{1}$ Тореро на кокосовом субстрате. Достоверно доказано, что искусственное освещение томата положительно влияет на продуктивность и биометрические показатели растений.

\section{Библиографический список}

1.Производство тепличных томатов выросло на 25\% [Электронный ресурc]. URL: http://www.agroinvestor. ru/analytics/news/29240-proizvodstvo-teplichnykhtomatov-vyroslona-25/ (дата обращения: 20.09.2018)

2.Башков А.С., Леконцева Е.В., Иванова Т.Е. Влияние многофункциональных удобрений на урожайность озимого чеснока и получение оздоровительного посадочного материала в условиях Удмуртской Республики // Аграрный вестник Урала, 2014. № 9. С. 58-61.

3.Коробейникова О.В. Фитоспорин-М на томате // Картофель и овощи. 2016. № 6. С. 16-17.

4.Лебедева М.А., Тутова Т.Н. Влияние сорта на продуктивность и качество плодов томата // Вестник Ижевской государственной сельскохозяйственной академии. 2013. № 2 (39). С. 98-100.

5.Удобрение картофеля / Е.В. Лекомцева, Т.Е.
Иванова, И.Л. Иванов, Т.Ю. Бортник // Картофель и овощи. 2015. № 4. С. 34-35.

6.Мерзлякова В.В. Соколова Е.В., Сентемов В.В. Микроэлементы с макропользой // Гавриш. 2015. № 2. C. 34-39.

7.Несмелова Л.А. Федоров А.В. Корреляционная связь биометрических показателей листовой редьки с климатическими факторами Удмуртской Республики / Инновационные технологии для реализации программы научно-технического развития сельского хозяйства: материалы Всерос. научн.- практ. конф. Ижевск: ФГБОУ ВО Ижевская ГСХА, 2018. Т. 1. С. 86-90.

8.Соколова Е.В., Мерзлякова В.М. Новые томаты для защищенного грунта / Е.В. Соколова // Гавриш. 2017. №2. С. 32-37.

9.Соколова Е.В., Мерзлякова В.М. Перспектива использования новых гибридов томата защищенного грунта / Научно обоснованные технологии интенсификации сельскохозяйственного производства: материалы Международной научн.- практ. конф. Ижевск: ФГБОУ ВО Ижевская ГСХА, 2017. Т. 1. С. 102-104.

10.Соколова Е.В., Мерзлякова В.М., Коробейникова О.В. Гибриды томата для защищенного грунта Удмуртии // Картофель и овощи. 2018. № 7. С. 39-40.

11.Соколова Е.В., Мерзлякова В.М. Эффективность субстратов при выращивании индетерминантных гибри дов томата в зимне-весеннем обороте. Реализация принципов земледелия в условиях современного сельскохозяйственного производства: материалы Всерос. научн.практ. конф., посвященной 85-летию со дня рождения доктора с.- х.н., проф. В.М. Холзакова. Ижевск: ФГБОУ ВО Ижевская ГСХА, 2017. Т. 1. С. 221-224.

12.Тутова Т. Н. Влияние сорта на урожайность и качество плодов томата / Агрономическому факультету - 60 лет: материалы Всерос. научн.- практ. конф.ФГБОУ ВО Ижевская ГСХА, 2014. С. 157-158.

13.Доспехов Б.А. Методика полевого опыта. М.: Агропропромиздат, 1985. $351 \mathrm{c}$.

\section{Об авторах}

Соколова Елена Владимировна, канд.с. - х. наук, доцент кафедры плодоводства и овощеводства, ФГБОУ ВО Ижевская государственная с. - х. академия (Ижевская ГСХА)

Мерзлякова Вера Михайловна, канд.с. - х. наук, доцент кафедры химии, ФГБОУ ВО Ижевская ГСХА. Тел. +7 (912) 446-60-30.

E-mail: merzlyakova.vera@bk.ru

Productivity and biometric indicators of tomato fruits depending on the illumination

E.V. Sokolova, PhD, associate professor, department of fruit and vegetable, Izhevsk State Agricultural Academy.

V.M. Merzlyakova, $P h D$, associate professor, department of chemistry, Izhevsk State Agricultural Academy.

Phone: +7 (912) 446-60-30

E-mail:merzlyakova.vera@bk.ru

Summary. Indeterminate hybrid of tomato $\mathrm{F}_{1}$ Torero on coconut substrate can be recommended for cultivation in protected soil in the conditions of the Udmurt Republic. The results of the 2017-2018 studies showed that the illumination influenced the number of fruits on the plant ( $R=0.56$ and 0.71 , respectively) and the number of fruit-bearing brushes on the plant ( $R=0.90$ and 0.82 , respectively).

Keywords: tomato, yield, winter-spring turnover, illumination, protected ground, tomato biometric indicators 